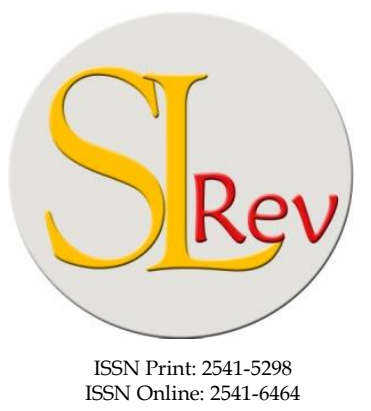

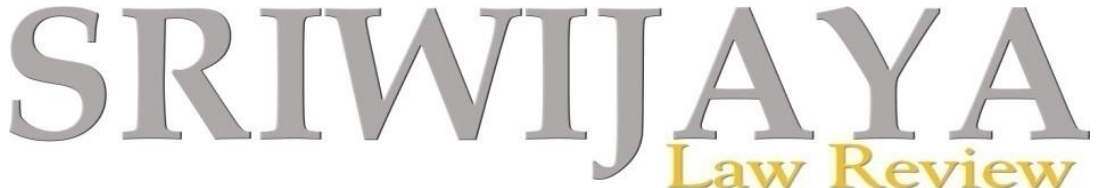

Editorial Office: Faculty of Law, Sriwijaya UniversityJalan Srijaya Negara, Palembang, South Sumatra 30139, Indonesia. Phone: +62711-580063Fax: +62711-581179

E-mail: sriwijayalawreview@unsri.ac.id| sriwijayalawreview@gmail.com Website: http://journal.fh.unsri.ac.id/index.php/sriwijayalawreview

\title{
Does the International Community Have Efforts to Protect the Marine Environment from Seabed Mining?
}

\author{
Idris $^{\mathrm{a}^{*}}$ and Taufik Rachmat Nugraha ${ }^{\mathrm{a}}$
}

a Corresponding Author. Faculty of Law, Universitas Padjadjaran, Bandung, Indonesia. E-mail: idris@unpad.ac.id

\begin{tabular}{|c|c|}
\hline Article & Abstract \\
\hline $\begin{array}{l}\text { Keywords: } \\
\text { International Seabed } \\
\text { Authority; Marine Envi- } \\
\text { ronment; Seabed Min- } \\
\text { ing; Sustainable Devel- } \\
\text { opment Goals. }\end{array}$ & $\begin{array}{l}\text { Through the United Nations, the international community is seriously paying } \\
\text { attention to the use of seabed areas as regulated by the Law of the Sea Con- } \\
\text { vention 1982, which states that the area and its resources are the common her- } \\
\text { itage of humankind. The } 1994 \text { Agreement has implemented chapter XI. The } \\
\text { resources are relating to the state's interests in terms of energy exploration and } \\
\text { environmental impact aspects. An increasing need for global electronic prod- } \\
\text { ucts by many countries in which of the components are rare minerals. Various } \\
\text { minerals such as manganese, polymetallic nodules, and polymetallic sulphur } \\
\text { are lying down in the seabed. However, seabed also had an essential role in } \\
\text { keeping the marine ecosystem balanced. On the one hand, the human's need } \\
\text { for those minerals also cannot be denied. Draft of regulations by the Interna- } \\
\text { tional Seabed Authority to manage deep-sea mining are still insufficient to } \\
\text { prevent irrevocable damage to the marine ecosystem and loss of essentials } \\
\text { species for the next. On the other hand, the spirit of Sustainable Develop- } \\
\text { ment Goals } 14 \text { concerns life underwater. This paper examines deep-sea min- } \\
\text { ing science from a legal perspective to protect and preserve seabed for the fu- } \\
\text { ture generation using normative approach describing norms and princi- } \\
\text { ples in the Law of the Sea Convention 1982. As a result, the commerciali- } \\
\text { sation of deep-sea mining violates the principle of the convention. } \\
\text { Thus, it needs to encourage ISA to enhance the minimum requirements } \\
\text { for all contracting parties in the future. }\end{array}$ \\
\hline \multicolumn{2}{|c|}{$\begin{array}{l}\text { (O2021; This is an Open Access Research distributed under the term of the Creative Commons Attribution License } \\
\text { (https://Creativecommons.org/licences/by/4.0), which permits unrestricted use, distribution, and reproduction in } \\
\text { any medium, provided the original works is properly cited. }\end{array}$} \\
\hline
\end{tabular}

\section{INTRODUCTION}

Law of the Sea Convention 1982 (LOSC 1982) is one of the most successful treaties ever made to regulate oceans. ${ }^{1}$ The Convention 1982 comprises 17 chapters, 320 articles, and nine annexes governing all aspects of ocean spaces from maritime delimitations, international navigation, ma-

1 "LOSC or UNCLOS or the Convention 1982 (United Nations Convention on the Law of the Sea) Was Adopted on 10 December 1982 by 119 States and Entered into Force on 16 November 1994. Now States Parties of the Convention Is 168 States per 3 April 2018.," n.d. 
rine pollution, and natural resources, either biotic or abiotic ecosystem, from national waters to the seabed subsoil beyond the limits of national jurisdiction so-called the area. "The Area means the seabed and ocean floor and subsoil thereof, beyond the limits of national jurisdiction", as stated by Art 1 (1) of the LOSC 1982.

Seabed minerals were discovered in the late 19th century, and since then, seabed minerals have got some attention from developing countries. The deep seabed has located beyond the limits of national jurisdiction, known as "the area". ${ }^{2}$ Seabed mining is considered an alternative solution to reach some strategic minerals such as $\mathrm{Cu}, \mathrm{Ni}, \mathrm{Co}, \mathrm{Pb}, \mathrm{Zn}$ and $\mathrm{Cd}^{3}$ As we have seen today, it is essential to support modern life, ${ }^{4}$ to eliminate economic imbalances between the "north and south dilemma" by alleviating the poverty of emerging states that their area containing seabed minerals to be exploited. Furthermore, these emerging states are located in the Pacific Ocean, such as Tonga and Fiji. In the ASEAN region, Singapore, as the only ASEAN member state, has been prepared its seabed mining regulation through its national legislation. ${ }^{5}$

The area has a unique status and is slightly different from high seas regimes with no specific authorities to regulate. Furthermore, Article 136-137 of the LOSC describes that:

"The Area and its resources are the common heritage of humankind (CMH) that no state shall claim or exercise sovereignty or sovereign rights over any part of the area or its resources, nor shall any state or natural or juridical person appropriate any part thereof, ...no such claim or exercise of sovereignty or sovereign rights nor such appropriation shall be recognised; Therefore, the area is vested in humankind as a whole, on whose behalf the Authority shall act for that resources."

Seabed mining has to get more attention for decades when mining technology is more developed to answer world demand for rare minerals. The ocean floor is unique which it contains minerals often enriched instead to the terrestrial environment. Hence this fact is one of the driving forces behind the LOSC 1982, which convened between 1972 and 1982. ${ }^{6}$ Furthermore, the LOSC 1982 in Chapter XI has stipulated the activities in the area must be benefited for humankind regardless of their economic degree, and technologies ${ }^{7}$ and there is neither jurisdiction nor sovereign rights over the area and is likely extended to a person or private rights or generally known as a nonappropriation principle. ${ }^{8}$ this "special chapter" on the LOSC 1982 is not a theoretical movement. Nevertheless, as CMH principle, which laying down from Art 136 to 141, the LOSC 1982.

According to the International Seabed Authority (ISA), the area has particular jurisdiction for all kinds of activities, which shall be governed under an international regime enacted through LOSC 1982. Furthermore, all the contractors and contracting states who intend to explore and exploit minerals in the area should have cooperation and authorisation from the ISA and regulatory

2 Rakhyun E. Kim, “Should Deep Seabed Mining Be Allowed?," Marine Policy 82 (2017): 134-37.

$\mathrm{Cu}=$ Copper, $\mathrm{Ni}=$ Nickel, $\mathrm{Co}=$ Cobalt, $\mathrm{Pb}=\mathrm{Lead}, \mathrm{Zn}=\mathrm{Zinc}$ and $\mathrm{Cd}=$ Cadmium. Periodical Tables for specifications.

4 Raul Sharma, "Environmental Issues of Deep-Sea Mining," Procedia Earth and Planetary Science 11 (2015): 204-11.

5 https://www.isa.org.jm/national-legislation-database, accessed on 25 May 2019.

6 "Strengthening Deep Seabed Mining Regulation, A Series of Papers on Policy Options, Prepared for the Third Meeting of the Global Ocean Commission," Eu-Midas, 2013, https://www.eu-

midas.net/sites/default/files/publications/GOC-paper05-seabed-mining.pdf.

7 The Law of The Sea Convention 1982, Art 137, Chapter IX.

8 The Law of The Sea Convention 1982, Art 137, Chapter IX. 
body. According to the 1994 Agreement, ISA has a particular system to the divided area and its mineral among contracting parties. ${ }^{9}$

Seabed mining interest has ever been dampened after world metal prices were collapsed significantly. However, the world situation has changed dramatically with developing sophisticated technologies concurrently. Human demand for rare minerals is the vital point of technological development in peak movement, concluding high demand on rare mineral supply. However, the terrestrial environment was in the peak of production, which might be as the "top out" of mineral production will not for much longer ${ }^{10}$ in this circumstance.

Henceforth, seabed mining shall be highly considered an environmental issue. As described by ISA, the benefit of humankind interpreted either economics or financial interest exclusively, albeit social and environmental interest, in particular for future generations, shall deserve equal consideration. $^{11}$ Following SDGs 14 Sustainable Development Goals 14 (SDGs) By 2025, prevent and significantly reduce marine pollution of all kinds, in particular from land-based activities, including marine debris and nutrient pollution ${ }^{12}$ seabed mining potentially harming living resources in the area falls into two broad areas: causal physicochemical changes and biological response. $^{13}$

One of the world's future challenges is "Marine Pollution," and to overcome its problem, global leaders are agreed to create Millennium Development Goals (MDGs), which have aimed to mitigate future challenges, not become a catastrophe for humankind, and MDGs in 2015 have changed into Sustainable Development Goals (SDGs). The United Nations Development Programme (UNDP) has been one of the leading organisations working to achieve the SDGs. This organisation is present in more than 170 countries aimed to fulfil the SDGs goals, including life below water in SDGs no $14 .^{14}$

Goal 14 of the SDGs is Life below Water concerns conservation and wisely use the oceans, including seas and marine resources, for sustainable development. The oceans face hazardous pollution sources, especially from plastic wastes and overfishing of the fish stocks. The experts stated that the ocean absorbs about thirty per cent of the carbon dioxide of human activities on the one hand, but the water will be more acidic by climate change. Therefore, the effort to achieve targets for managing and protecting life below water, including exploring and exploiting the seabed.

Based on the ground facts deserved, this paper will examine: First, analyse current seabed scientific research activities in correlation with the common heritage of humankind principles. Sec-

9 Guobin Zhang and Pai Zheng, “A New Step Forward: Review of China’s 2016 Legislation on International Seabed Area Exploration and Exploitation, Marine Policy,” Marine Policy 73 (2016): 244-55.; Zou Keyuan, China's Marine Legal System and the Law of the Sea 2005. p. 167.

10 Richard A. Kerr, “The Coming Copper Peak,” Science 434, no. 6172 (2014): 722-24.

11 Kim, "Should Deep Seabed Mining Be Allowed?"

12 "Sustainable Development Goals 2030 No. 14 on Conserve and Sustainably Use the Oceans, Seas and Marine Resources for Sustainable Development," n.d., https://sustainabledevelopment.un.org/sdg14.

13 Cindy Lee Van Dover, "Impacts of Anthropogenic Disturbances at Deep-Sea Hydrothermal Vent Ecosystems: A Review," Marine Environmental Research 102 (2014): 59-72.

14 Seventeen goals of the SDGs by United Nations General Assembly No. A/RES/70/1, 21 October 2015 Seventieth session, Resolution adopted by the General Assembly, 25 September 2015 on Transforming our world: the 2030 Agenda for Sustainable Development. The topic is relating to Goal 14 about L. 
ond, analyse SDGs 14 regarding "living below the ocean" to answer the future challenge on deepsea mining through a legal perspective. Moreover, this paper will end with a concluding remark.

\section{RESEARCH METHOD}

This research mainly uses the legal-descriptive and normative approach describing norms and principles in Chapter XI LOSC 1982 and reflect the definition of the source of international Law under Article 36 (1) International Court of Justice (ICJ) Statute and comparison studies between China and Indonesia. In order to give insight and an in-depth understanding of seabed mining, a benchmark will be needed. For that reason, an element of scientific and technological approach presents in this research. Furthermore, the doctrinal approach is also essential in this research. All relevant legislation and case law will be analysed to reveal a statement of the Law relevant or the most possible to seabed mining activities. One part of this study is descriptive or lege lata, in which it will clarify the legally binding nature of the LOSC 1982. Another part of the study will be normative or lex ferenda. This research will deal with environmental matters to preserving the future ocean for future generations through SDGs 14.

\section{ANALYSIS AND DISCUSSION}

\section{Common Heritage of Mankind on Seabed Accordance within Legal Framework}

The first influence regarding $\mathrm{CMH}$ is undoubtedly coming from Arvid Pardo speech as Malta Ambassador at General Assembly in August 1967. ${ }^{15}$ Arvid Pardo affirms, "the seabed and the ocean floor are the common heritage of mankind and should be used and exploited for peaceful purposes and the exclusive benefit of mankind as a whole". This principle was also introduced into space law. Indeed, this principle on the Law of the sea is more advancing. ${ }^{16}$ Art 136 of the LOSC 1982 elaborated upon Art 137, 140, and Art 141 of the Convention will result in some degree of legal clarity to the concept of $\mathrm{CMH} .{ }^{17}$ Over the decades, the $\mathrm{CMH}$ principle has been attracted many legal experts and causing pros and cons within, mainly if the $\mathrm{CMH}$ principle applied over the legal status of common space areas, in this meant ocean floor.

Before LOSC 1982, there were three different legal points regarding natural resources beyond national jurisdiction. ${ }^{18}$ Firstly, the ocean floor and its contained would be divided among the coastal state. Secondly, the ocean floor and all-natural resources inside would be considered to res communis means will be subject under the freedom of the high seas. Thirdly, the ocean floor and its natural resources will be the res nullius area. In this provision, the mining state would be appropriate for the ocean floor, and it contains occupation (first come, first serve basis).

At the UN Resolution, 2479 first Article stated, "the seabed and ocean floor and subsoil thereof, beyond of limits national jurisdiction, as well as a resource the area, are the common heritage of humankind. ${ }^{19}$ At the LOSC 1982, this principle can be seen in Art 136 that "The Area and its resources are the common heritage of mankind" if we want to understand what is (resources) it may

15 Siavash Mirzaee, "The Conceptual Foundations of the Common Heritage of Mankind," Journal of Advanced Research in Law and Economics 9 (2018): 50-54.

16 Michael W. Lodge, "The Common Heritage of Mankind," The International Journal of Marine and Coastal Law 27 (2012): 733-42.

17 Lodge.

18 Robin Churchill and Vaughan Lowe, The Law of the Sea (Manchester University Press, 1999).

19 “UNGA Resolution 2479 (XXV) 1969," n.d. 
be referred to Art 133 "means all solid, liquid, or gaseous mineral resources in situ in the area or beneath the seabed, including polymetallic nodules." 20

CHM is an essential element on the LOSC 1982 as a tertium genus applied to particular sea resources and in a particular area on the sea. ${ }^{21}$ Furthermore, CMH had three legal elements consist: first, there is no freedom of exploration and exploitation based on the appropriation of the area on the basis sovereignty principles is negated. In this regard, the common space area would be owned by no one and will be managed by everyone to prevent any future dispute among nations, and everyone means ISA (International Seabed Authority). They have complete control over the ocean floor area. Secondly, the elements should be a concern for the benefit of humankind as a whole. ${ }^{22}$ All of the financial and economic benefits of exploiting common space areas must be shared internationally under the CHM principle. ${ }^{23}$ Furthermore, if we carefully read the equitable principle, the last also affected Art 140 (2) LOSC 1982 mentioned. Third, the area should use for "peaceful purposes" by all States. Moreover, what is by meant terms "Peaceful purposes", According to Article 10 of UN Res 2479, all states should encourage cooperation in strengthening scientific research among all states. ${ }^{24}$

Furthermore, the background of the 1994 implementing agreement being made is to comply with the U.S. interest and objection to Chapter XI. ${ }^{25}$ Chapter IX LOSC 1982 was tremendously innovative because it provided the parallel system, production policies, technology transfer, financial terms of contracts, and review conference. ${ }^{26}$ Unfortunately, industrialised states had objections regarding Chapter XI LOSC 1982. As enunciated by the Reagan administration, the U.S. Policy regarding the 1982 Convention summarised as follows: "while most of the draft Convention is acceptable and consistent with the U.S interest, some major element of deep seabed mining regime is unacceptable". ${ }^{27}$ In this regard, the U.S has voted against and did not sign the LOSC 1982. Meanwhile, some other industrialised states abstain due to objection.

By July 1990, the UN Secretary General initiated informal consultation to meet the objection of industrialised states. Furthermore, and its proceeds by his successor with those consultations and saw them to a conclusion. ${ }^{28}$ As a result, the general assembly accepted this Resolution at re-

20 Yoshifumi Tanaka, The International Law of The Sea (Cambridge University Press, 2012).

21 Tullio Scovazzi, "The Concept of Common Heritage of Mankind and the Genetic Resources of the Seabed beyond the Limits of National Jurisdiction," Agenda International 14, no. 25 (2007): 11-24.

22 Article 140 stated as follows; "Activities in the Area shall, as specifically provided for in this Part, be carried out for the benefit of mankind as a whole, irrespective of the geographical location of States, whether coastal or landlocked and taking into particular consideration the interests and needs of developing States and of peoples who have not attained full independence or other self-governing status recognised by the United Nations under General Assembly resolution 1514 (XV) and other relevant General Assembly resolutions."

23 Elisabeth Mann Borgese, "The New International Economic Order and The Law of The Sea," San Diego Law Review 14 (1977): 584-90.

24 "UNGA Resolution 2479 (XXV) 1969."

25 Bernard H. Oxman, "Law of the Sea Forum: The 1994 Agreement on Implementation of the Seabed Provisions of the Convention on the Law of the Sea - The 1994 Agreement and the Convention," American Journal of International Law 88 (1994): 687-97.

26 Tanaka, The International Law of The Sea.

27 Statement by the President "Sustainable Development Goals 2030 No. 14 on Conserve and Sustainably Use the Oceans, Seas and Marine Resources for Sustainable Development."

28 "Sustainable Development Goals 2030 No. 14 on Conserve and Sustainably Use the Oceans, Seas and Marine Resources for Sustainable Development." 
sumed 141 in favour, none against, and 7 abstain. ${ }^{29}$ Moreover, the U.S has signed this Resolution. ${ }^{30}$ With President Reagan's criterion has been satisfied by the Resolution, the Senate later approved this agreement. The 1994 agreement core is to accommodate the U.S and other industrialised states objection at Chapter XI. Then the agreement was changed into market-oriented based by eliminated some identified as the problem, such as limitation of production, mandatory transfer of technology, and academic conferences to exchange the view among the scientists.

\section{Current Activities on the Area and Its Impact on the Environment}

ISA result from LOSC 1982 as refined from 1994 agreement to implementation Chapter XI LOSC1982 regarding Seabed provision. ${ }^{31}$ Furthermore, ISA has the primary duty to organise, share the benefit, and control all the activities in the area to prevent any hazardous contamination in the vulnerable ecosystem resulting from such activities. ${ }^{3233}$ The seabed authority had rationa materice in this regard. The Authority does not have competencies beyond Activities on the seabed and subsoil, as Art 145 mentioned. These activities exclude fishing, shipping, bioprospecting for genetic resources, marine scientific research in general, and laying cables and pipelines beyond seabed competencies. ${ }^{34}$

According to Michael W. Lodge, "in 2000 or six years after ISA establishment, the ISA had a significant milestone in the work of the authority the Convention of all the claims to exploration site registered under the pioneer regime that had applied pending entry into force of the Convention into legally binding contracts of limited duration under the Conventions." It was done through the adoption in July 2000 of regulations governing exploration for the polymetallic nodules, including standards clauses for contracts. ${ }^{35}$

Under current development, ISA has twenty-seven contracts. It is divided into several segments, such as six contracts to explore polymetallic nodules in the area 'Clarion-Clipperton fracture zone and Indian ocean basin. Another six contracts were devoted to exploring polymetallic

29 GA Res 48/263 (1994)

30 The U.S sixth objection has been fulfilled and satisfied through this Resolution; those objections were: "the nation's need development for the seabed should be based the rule of the area by the Committee of the Area, assure national access to these resources by current and future qualified entities to enhance U.S. security of supply, to avoid monopolisation of the resources by the operating arm of the international Authority, and to promote the economic development of the resources, provide a decision-making role in the deep seabed regime that fairerflecks and effectively protects the political and economic interests and financial contributions of participating states, not allow for amendments to come into force without the approval of the participating states, including, in our case, the advice and consent of the Senate, not set other undesirable precedents for international organisations, and be likely to receive the advice and consent of the Senate. In this regard, the convention should not contain provisions for the mandatory transfer of private technology and participation by and funding for the national liberation movement." Statement by the President 29 January 1982“Sustainable Development Goals 2030 No. 14 on Conserve and Sustainably Use the Oceans, Seas and Marine Resources for Sustainable Development."

31 Nii Allotey Odunton, "Nii Allotey Odunton, The International Seabed Authority: It's Roles, Organ and Function."

32 The area means "the seabed on the ocean floor and subsoil thereof beyond national jurisdiction", and based on dispute chamber of ITLOS cleared the term "Activities on the Area" consist of: "drilling, dredging, coring, and excavation: disposal, dumping and discharge into marine environment sediment, wastes or other effluents; and construction and operation or maintenance of installation, pipelines and other devices related to such activities." In the report of ITLOS decision, Responsibilities and Obligation of States Sponsoring Persons and Entities concerning Activities in the Area, Case No.17 1 February 2011, P. 28, Para. 87.

33 Article 145 LOSC.

34 Martha Chantal Ribeiro, "What Is the Area and the International Seabed Authority?," www.institut-ocean.org.

35 Lodge, "The Common Heritage of Mankind." 
sulfide in the southwest Indian ridge (figure 2). The rest is for cobalt-rich ferromanganese areas. ${ }^{36}$ Each contract has a covered area of exploration up to $150.000 \mathrm{Km}^{2}$. The total coverage area of twenty-seven contracts is up to $1.315 .633 \mathrm{Km}^{2}$ of the deep sea bed, but the final coverage area to the contractor just only $811.597 \mathrm{Km}^{2} .^{37}$ The newest contract was signed by China Minmetals Corporation, which started on 12 May 2017 and will determine on 11 May 2032. Afterwards, the map of the contracting area can be seen in Figures 1 and 2.

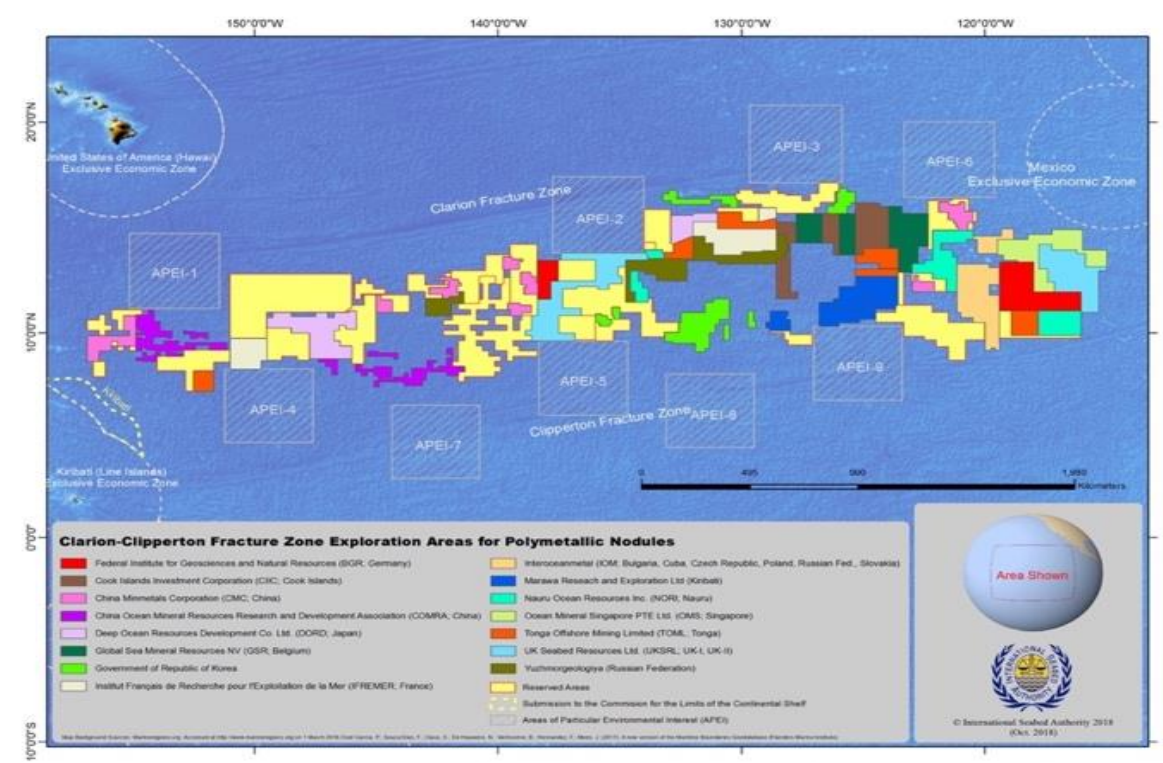

Figure 1: Clarion-Clipperton Zone (CCZ) Reserved Area of PMN, which consist of sixteen contracts up to $2032^{38}$

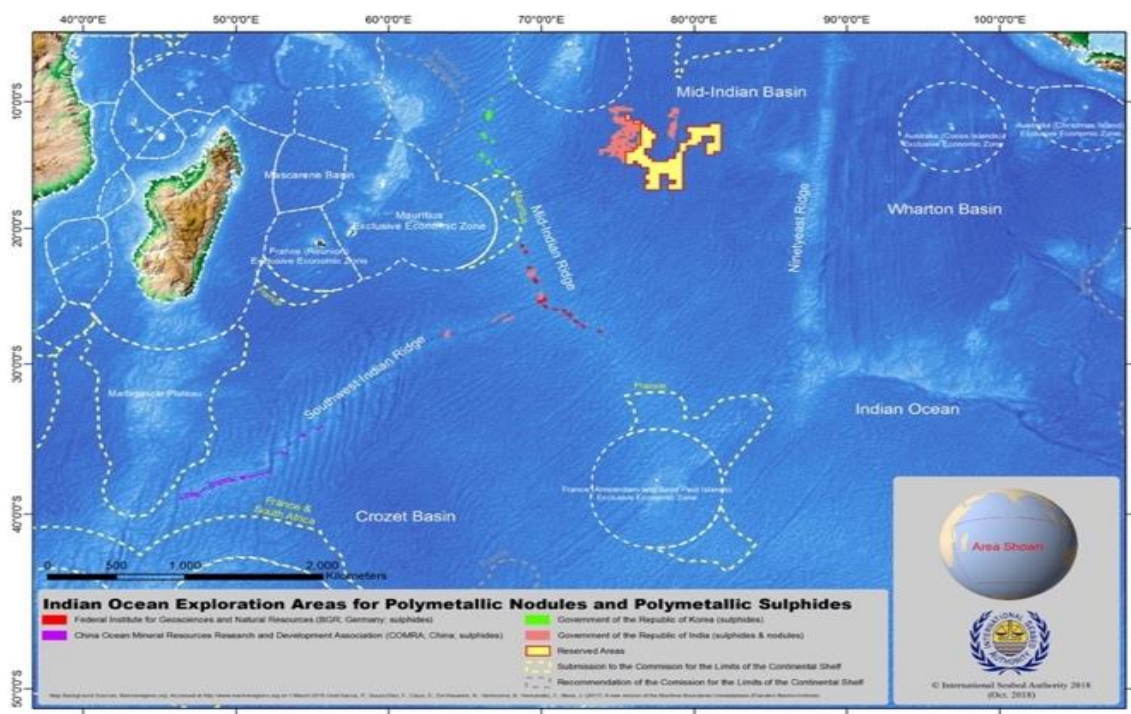

Figure 2: CIOB (Central Indian Ocean Basin) Reserved Area of PMN, which consist of one contract by the Government of India and a contract extended up to $2022^{39}$

\footnotetext{
36 “International Seabed Authority," 2019, https://www.isa.org.jm/deep-seabed-minerals-contractors/overview.

37 “As Data Per-January 2019 Based on Current Status of the Reserved Areas," International Seabed Authority, 2019, https://ran-s3.s3.amazonaws.com/isa.org.jm/s3fs-public/files/documents/statusofreservedareas-01-2019a.pdf.

38 International Seabed Authority, https://www.isa.org.jm/contractors/reserved-areas, accessed 30 July 2021.

39 International Seabed Authority, https://www.isa.org.jm/contractors/reserved-areas, accessed 30 July 2021.
} 
Developing countries have sponsored current development on the reserved area exploring in the area. In 2011, Nauru Ocean Resources Inc (NORI) was given an exploration contract over four sub-areas taken from the reserved areas contributed by Bundesanstalt für Geowissenschaften und Rohstoffe (BGR) from Germany, ROSGEO from Russian Federation and Interocean metal Joint Organization (IOM). In the same year, Tonga Offshore Minerals Ltd (TOML) was given an exploration contract over six sub-areas from the reserved areas contributed by BGR, Deep Ocean Resources Development Co.Ltd (DORD) Japan, Republic of Korea, and IFREMER France. ${ }^{40}$ And for China Minmetals Corporation, the application was divided into eight blocks selected from five different reserved areas contributed by ROSGEO, IOM, and COMRA. ${ }^{41}$

Concurrently deep-sea mining or seabed mining is still in the exploration stage, at least for a decade later. However, the environmental issue as a side-impact from seabed mining must be considered early to mitigate unexpected catastrophes to the biotic and abiotic resources. Considering the negative impact on the environment, ISA currently is drafting "a mining code" including its environmental guidance for polymetallic sulphides and other mineral exploitation from the seabed in the area. ${ }^{42 ; 43}$

Deep-sea mining operations commonly understand as jeopardy activities that may negatively affect the marine environment due to sea bed mining activities. Further, there are significant negative consequences laid down. Firstly, Impact on the ocean floor, exploitation of the marine environment will have various impacts on the coastal area and the ocean floor. Basically, all activities involving changing the structure of the resources, including seabed mining, will contribute to change in sediments dynamics. ${ }^{44}$ Furthermore, seabed mining also has a chemical and biological concern affecting microbenthic such as protozoan, microbes, and microbes. In the deep sea, like oases of vibrant and exotic life dependent on that microorganism produce food using chemical energy through chemosynthesis, as shown in figure $3 .^{45}$ and convert detritus and dissolved organic material into particulates used by a larger organism, and nodules are natural habitats for various microbenthic ${ }^{46}$ It will affect the supply of the ocean food chain.

Seabed mining, like in figure 3, harms living, and non-living resources, most of the mining sites, are located near hydrothermal vents. Deep hydrothermal vents are like hot springs on the seafloor where mineral-rich, hot water flows into the otherwise cold, deep sea. Complete ecosys-

40 “As Data Per-January 2019 Based on Current Status of the Reserved Areas."

41 "As Data Per-January 2019 Based on Current Status of the Reserved Areas."

42 Et.al C.L. Van Dover, "Scientific Rationale and International Obligations for Protection of Active Hydrothermal Vent Ecosystems From Deep-Sea Mining," Marine Policy 90 (2018): 20-28.

43 ISA has enacted a comprehensive rule regarding deep-sea mining to regulate prospecting, exploration and exploitation of marine minerals, ISBA/6/A/18 approved on 2010 regarding prospecting and exploration for polymetallic sulphides in the area. ISBA/18/A/11 approved on 2012 regulating on Prospecting and Exploration for Cobalt-rich Ferromanganese Crusts in the Area. ISBA/19/A/9, ISBA/19/C/17 regarding the amendment to the Regulations on Prospecting and Exploration for Polymetallic Nodules in the Area and the Regulations on Prospecting and Exploration for Polymetallic Nodules in the Area and related matters.

44 Till Markus, Katrin Huhn, and Kai Bischof, “The Quest for Sea-Floor Integrity," Nature Geoscience 8 (2015): 163-64.

45 C.L. Van Dover, "Scientific Rationale and International Obligations for Protection of Active Hydrothermal Vent Ecosystems From Deep-Sea Mining."

46 Jefferey D. Wilson, "Mining the Deep Seabed: Domestic Regulation, International Law, and UNCLOS OOO," Tulsa Law Review 18, no. 2 (2013): 207-60. 
tems sprout up around these vents, and numerous organisms are supported by the energy given off at these rare sites. The direct impact of mining is changing seafloor structure.

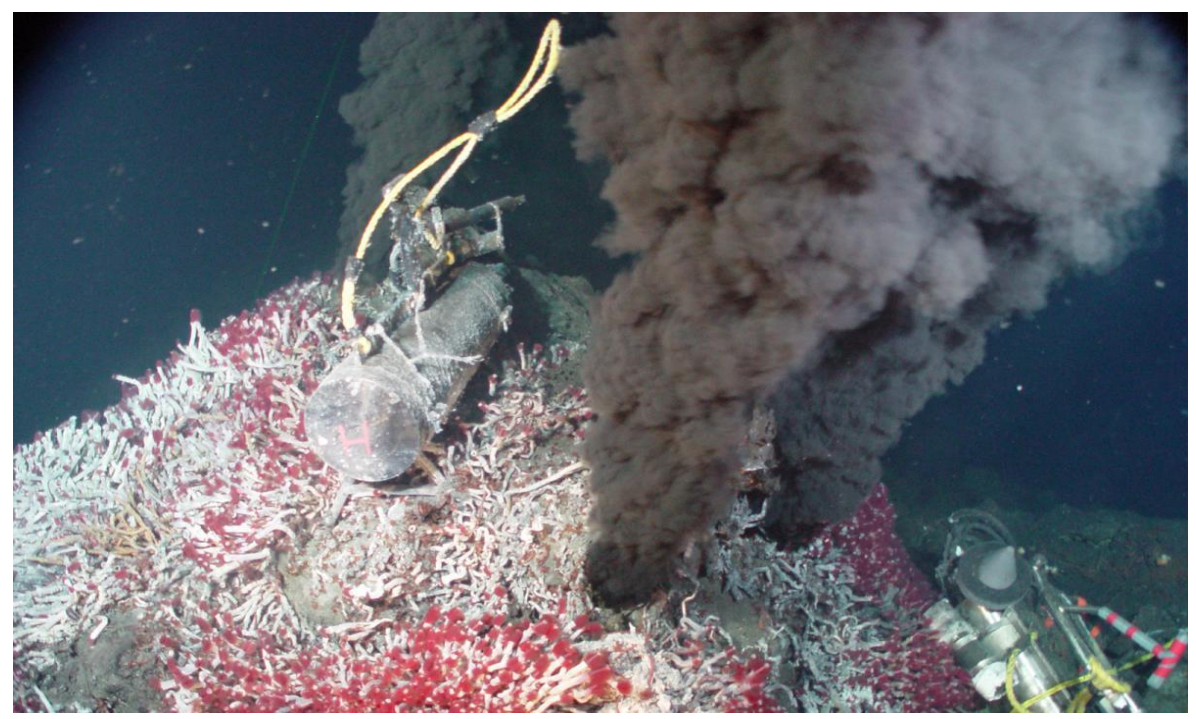

Figure 3: Deep hydrothermal vents ${ }^{47}$

Active hydrothermal vents have a high temperature around $350^{\circ} \mathrm{C}^{48}$ that release metal-rich fluids, these metals precipitate at the seafloor and forming polymetallic rich with copper and zinc element, in the other hand, polymetallic is highly associated with hydrothermal vents ${ }^{49}$ and it is accumulated up to thousands of years to form a metal-rich area as it is known today and become a significant interest to be exploiting.

According to an environmental report on Environment Impact Status (EIS) issued by Nautilus Minerals, Niugini Limited, generally known as "Solwara 1 Project, " was released directly from deep-sea mining activities on living non-living creatures. The result from Solwara 1 regarding living creatures on the area of Seafloor Mining Tool (SMT) stated "due to SMT activities by SMV all local organism nearby probably will be swept out and would not survive either rising to the surface or being sucked into cutter heads and RALS". ${ }^{50}$ However, this report only appeals to the miners to avoid and minimise environmental impacts at hydrothermal vents where possible from jeopardy activities. ${ }^{51}$

In short, according to the report has stated, the SMT and SMV has four significant potential effects could be given, ${ }^{52}$ firstly, direct destruction of the deep-sea habitat is a mortality of benthic organisms related to the living resources mutual relation. Secondly, suspended solids and re-

47 Marine Science and Ecosystems Deep Hydrothermal Vent, https://oceana.org/marine-life/marine-science-andecosystems/deep-hydrothermal-vent, accessed on 31 July 2021.

48 C.L. Van Dover, "Scientific Rationale and International Obligations for Protection of Active Hydrothermal Vent Ecosystems From Deep-Sea Mining."

49 Et.al R. E. Boschen, "Mining of Deep-Sea Seafloor Massive Sulfides: A Review of The Deposits, Their Benthic Communities, Impacts from Mining, Regulatory Frameworks and Management Strategies," Ocean and Coastal Management 84 (2013): 54-67.

50 Solwara 1 Project, "Environment Impact Statement, Nautilus Minerals Niugini Limited," Coffey Natural Systems A (2008): 9-24.

51 C.L. Van Dover, "Scientific Rationale and International Obligations for Protection of Active Hydrothermal Vent Ecosystems From Deep-Sea Mining."

52 Et.al Teruyoshi Narita, "Summary of Environmental Impact Assessment for Mining Seafloor Massive Sulfides in Japan,” Journal of Shipping and Ocean Engineering 5 (2015): 103-14. 
sedimentation due to plume formation causing by a dead benthic organism in surrounding waters resulting from being buried during re-sedimentation of suspended solids. Thirdly, during the activities, SMT will pump water SMV containing rich-minerals elements to the surface and pumped it back to the ocean, consisting of suspended solid and toxic metals and dead living creatures. Changing the composition of phytoplankton would affect the biological communities, including fish populations in the surface and mid-waters layers responsible for the primary production. Finally, noise from the activities is potentially influence behaviour of the marine mammals' likely whales, dolphin, and sea lions. The light will be attracting deep-sea living creatures and would be stuck on the SMT unit. Moreover, suspended materials from the SMT may contain hazardous chemical elements such as $\mathrm{AsH}_{3}$ (Arsine) and $\mathrm{Hg}$ (Mercury). ${ }^{53}$

\section{Deep-Sea Mining between China and Indonesia Legislations}

As this paper mentioned earlier regarding countries involved in exploring the area, some Asian nations have stepped further into the exploration, such as Japan, the Republic of Korea, PRC, and India. Henceforth, the area in this term is lying down beyond national jurisdiction according to Chapter IX the LOSC 1982. However, with the increase in the number of states activities in the area, we shall consider national interest in the area. Although PRC is currently one of the most leading countries that have actively engaged in the exploration up to four times, this fact shows that there must be no gap between the international law regime and national legislation.

Furthermore, through the ISA regulation, any contractor or countries that have an interest to explore the area shall be made cooperation with the ISA in order to satisfy the 1994 agreement. ${ }^{54}$ Furthermore, to fill the gap, China has the effort to make their national legislation. It had begun in 1988 when China enacted Law on the Exclusive Economic Law and Continental Shelf and 1992 law on the territorial sea and contiguous zone, both documents standing as a fundamental law for mining activities regulation in China. Thus, in 2014 the National People Congress (NPC), on the commission of environment and resources protection, began drafting Law on Exploring and Exploiting Resources in Deep Seabed Area. Finally, in 2016 China adopted its national legislation to protect PRC interest and the $\mathrm{CMH}$, namely, deep seabed area resource exploration and exploitation law of the Republic of China or deep seabed law. ${ }^{55}$ This Law at least contains 7 Chapters and 29 Articles. ${ }^{56}$

Seabed law has several key points to be considered, such as Personal Jurisdiction. State jurisdiction over persons and property necessarily includes actions in its national territory through its national legislature and national courts. ${ }^{57}$ yet some national jurisdiction could be extended in exceptional circumstances, such as on the vessel flying its national flag. It is applied to all personnel onboard regardless of their nationality, as LOSC 1982 stated.

53 Teruyoshi Narita.

54 Zou Keyuan, "China's Marine Legal System and the Law of the Sea," Chinese Journal of International Law 6, no. 1 (2005): 259-60.

55 Zhang and Zheng, "A New Step Forward: Review of China's 2016 Legislation on International Seabed Area Exploration and Exploitation, Marine Policy."

56 Keyuan Zou, "State Practice in Deep Seabed Mining: The Case of the People's Republic of China," Ocean Resource Governance Chapter 9 (2017): 185-203.

57 Zhang and Zheng, "A New Step Forward: Review of China's 2016 Legislation on International Seabed Area Exploration and Exploitation, Marine Policy." 
As one of the contracting states, China is concerned about protecting the ocean from hazardous material due to exploration and exploitation activities in the area through its national legislation. The protection has several steps to keep practicable, such as; applying high-end technologies, Marine Environment Assessment (MEA) to measure its exploration and exploitation activities and take precautionary measures for a vulnerable ecosystem in the area surrounding. ${ }^{58}$ Furthermore, protecting the natural marine environment, including its species, either threatened or endangered, is a fundamental concern from this national legislation to protect when exploration and exploitation begins. ${ }^{59}$

Concurrently, under Law No 4 the Year 2020 (Mining Act), Indonesian Law does not distinguish among those mining-based to utilise (minerals) resources between land-based and sea-based resources as Art 1 mentioned as follow: "art of all of the phases of activities in the framework of research, management and exploitation of minerals or coal, which include general investigation, exploration, feasibility study, construction mining, processing and refining, transportation and sales, and post-mining activities." Mining Act 2020 does not seem much mention seabed mining. In Art 1 (28) para a have mentioned "water column" and "continental shelf" and in Art 17 (2) if there any parties have intent to mining in "water column" the permit will be an issue by the ministry (of energy and mineral resources) after having a consultation with associated institutions. Moreover, there is still a lack of regulation on seabed mining in Indonesia.

\section{Deepsea Mining Within SDGs 14 Framework}

According to the current development and future challenge of the marine environment, ISA should have primary consideration to protect and preserve marine non-living resources exploitation being a catastrophe and affecting all communities. Hence, this fact is one driving force to made SDGs 14 to make sustainable development on the oceans for the future generation. Furthermore, ISA has dealt with "life below water" and calls for the "conservation and sustainable use of the oceans, sea and marine resources for sustainable development" ${ }^{60}$ Further, from 10 targets for SDGs 14, the ISA makes a relevant contribution towards the possible attainment of SDG 14.2 "Sustainable Management and Protection of Marine and Coastal Ecosystem and Strengthening resilience" SDG 14.5 "Marine Protected Areas and Effective Management plants. ${ }^{61}$ Furthermore, SDG 14.5 is strongly interweaving with seabed mining in the area. Concurrently ISA engaged in establishing EMP (Environmental Management Plans) and its strategies in the area in particular. The ISA contracted areas in the Atlantic, Indian Ocean, and the Pacific Ocean, which is the basis area of CCZ, $\mathrm{CIOB}$, and PMN.

Those initiatives from ISA have challenges due to confrontation by most national jurisdictions. The importance of getting credible data regarding the impact of exploration and exploitation activities from preserving such a unique area is one of the challenges the ISA faces. Furthermore, conducting marine research to collect data, including its process, is pricey for the contractors. It

58 https://ran-s3.s3.amazonaws.com/isa.org.jm/s3fs-public/files/documents/compstudy-nld.pdf.

59 Zhang and Zheng, "A New Step Forward: Review of China's 2016 Legislation on International Seabed Area Exploration and Exploitation, Marine Policy."

60 International Seabed Authority (ISA), "Contribution to the United Nations Secretary Generals Background Note for the Preparatory Meeting of the Unit-Ed Nations Conference to Support the Implementation of Sustainable Development Goal 14," n.d.

61 (ISA). 
seems complicated to disseminate to all parties that there is no support from the ISA. ISA has a unique approach to encouraging contracting parties through workshops, seminars, side events, and scholarships to answer this challenge. ${ }^{62}$

In the corridor of the spirit of SDGs 14 , ISA has achieved a great deal. ISA has developed various studies programs to enhance scientific knowledge through cooperation. These include the technical program on various issues, sponsoring international scientific initiatives, such as a model of CCZ and the Kaplan project ${ }^{63}$ To study species range and biodiversity in the same region. These various projects initiated or sponsored by ISA echo among the best scientist in the world and get full support and participation from developing countries, with more excellent projection to better understand marine resources and its environment for the benefit of future generations spirit on SDGs 2030.

Henceforth, contracting parties have a legal obligation to fund some programs to enhance and share their knowledge with other developing countries. Since 2011 there are 200 training programs globally and organised by the ISA, such as at-sea training, science and engineering training, fellowship programs, and postgraduate internship. ${ }^{64}$

\section{CONCLUSION}

The role of the seabed had a vital role in keeping marine living resources moving in, particularly in the hydrothermal area as likely oases in the middle of cold deep waters, which provide a rich resource for microbes to do chemosynthesis. Furthermore, if these areas were destroyed or damaged because of mining activities, it has not only "the area living creatures" will harm, but all over the ecosystem will be impacted. Various environment studies are concerned about this issue, and most likely, no one of those studies results in a piece of good news.

The future of the $\mathrm{CMH}$ principle is currently under question. After the contracts with ISA are increasingly very significant, we should be aware of seafloor living and non-living creatures, which mostly are undiscovered and still have become a great mystery. According to the data on this paper, it should be acknowledged that Deepsea mining has a significant potential impact on the ecosystem and is interwoven with the marine ecosystem incomprehensive. They argue that marine resources, either genetic or mineral, resources shall be considered part of the CMH. The utilisation or commercialisation of deep-sea mining violates the principle in LOSC. Thus, it needs to encourage ISA to enhance the minimum requirements for all contracting parties in the future. To ensure fragile ecosystems on the seabed are well protected, recalling the area also part of the heritage of humankind should be considered rather than economic and financial value. Moreover, Indonesia has the same opportunity as other states. If Indonesia wants to use the area, particular and comprehensive legislation should be made, especially regarding the environmental issue and scientific requirements as critical points for Indonesian companies as China did with their deepseabed mining act.

\section{REFERENCES}

Borgese, Elisabeth Mann. "The New International Economic Order and The Law of The Sea." San

62 (ISA). See ISBA/22/LTC/15

63 Lodge, "The Common Heritage of Mankind."

64 Lodge. 
Diego Law Review 14 (1977): 584-90.

C.L. Van Dover, Et.al. "Scientific Rationale and International Obligations for Protection of Active Hydrothermal Vent Ecosystems From Deep-Sea Mining." Marine Policy 90 (2018): 20-28.

Churchill, Robin, and Vaughan Lowe. The Law of the Sea. Manchester University Press, 1999.

Dover, Cindy Lee Van. "Impacts of Anthropogenic Disturbances at Deep-Sea Hydrothermal Vent Ecosystems: A Review.” Marine Environmental Research 102 (2014): 59-72.

"International Seabed Authority," 2019. https://www.isa.org.jm/deep-seabed-minerals-contractors/ overview.

International Seabed Authority. "Contribution to the United Nations Secretary Generals Background Note for the Preparatory Meeting of the Unit-Ed Nations Conference to Support the Implementation of Sustainable Development Goal 14," n.d.

International Seabed Authority. "As Data Per-January 2019 Based on Current Status of the Reserved Areas," 2019. https://ran-s3.s3.amazonaws.com/isa.org.jm/s3fs-public/files/ documents/statusofreservedareas-01-2019-a.pdf.

Kerr, Richard A. “The Coming Copper Peak.” Science 434, no. 6172 (2014): 722-24.

Keyuan, Zou. "China's Marine Legal System and the Law of the Sea." Chinese Journal of International Law 6, no. 1 (2005): 259-60.

Kim, Rakhyun E. "Should Deep Seabed Mining Be Allowed?” Marine Policy 82 (2017): 134-37.

Lodge, Michael W. "The Common Heritage of Mankind." The International Journal of Marine and Coastal Law 27 (2012): 733-42.

"LOSC or UNCLOS or the Convention 1982 (United Nations Convention on the Law of the Sea) Was Adopted on 10 December 1982 by 119 States and Entered into Force on 16 November 1994. Now States Parties of the Convention Is 168 States per 3 April 2018.," n.d.

Marine Science and Ecosystems Deep Hydrothermal Vent, https://oceana.org/marine-life/marinescience-and-ecosystems/deep-hydrothermal-vent, accessed on 31 July 2021.

Markus, Till, Katrin Huhn, and Kai Bischof. "The Quest for Sea-Floor Integrity." Nature Geoscience 8 (2015): 163-64.

Mirzaee, Siavash. "The Conceptual Foundations of the Common Heritage of Mankind." Journal of Advanced Research in Law and Economics 9 (2018): 50-54.

Odunton, Nii Allotey. "Nii Allotey Odunton, The International Seabed Authority: It's Roles, Organ and Function." 2011.

Oxman, Bernard H. "Law of the Sea Forum: The 1994 Agreement on Implementation of the Seabed Provisions of the Convention on the Law of the Sea - The 1994 Agreement and the Convention." American Journal of International Law 88 (1994): 687-97.

Project, Solwara 1. "Environment Impact Statement, Nautilus Minerals Niugini Limited." Coffey Natural Systems A (2008): 9-24.

R. E. Boschen, Et.al. "Mining of Deep-Sea Seafloor Massive Sulfides: A Review of The Deposits, Their Benthic Communities, Impacts from Mining, Regulatory Frameworks and Management Strategies." Ocean and Coastal Management 84 (2013): 54-67.

Ribeiro, Martha Chantal. "What Is the Area and the International Seabed Authority?" 2013. www.institut-ocean.org.

Scovazzi, Tullio. "The Concept of Common Heritage of Mankind and the Genetic Resources of 
the Seabed beyond the Limits of National Jurisdiction." Agenda International 14, no. 25 (2007): 11-24.

Sharma, Raul. "Environmental Issues of Deep-Sea Mining." Procedia Earth and Planetary Science 11 (2015): 204-11.

Eu-Midas. "Strengthening Deep Seabed Mining Regulation, A Series of Papers on Policy Options, Prepared for the Third Meeting of the Global Ocean Commission," 2013. https://www.eumidas.net/sites/default/files/publications/GOC-paper05-seabed-mining.pdf.

"Sustainable Development Goals 2030 No. 14 on Conserve and Sustainably Use the Oceans, Seas and Marine Resources for Sustainable Development," n.d. https://sustainabledevelopment. un.org/sdg14.

Tanaka, Yoshifumi. The International Law of The Sea. Cambridge University Press, 2012.

Teruyoshi Narita, Et.al. "Summary of Environmental Impact Assessment for Mining Seafloor Massive Sulfides in Japan.” Journal of Shipping and Ocean Engineering 5 (2015): 103-14.

“UNGA Resolution 2479 (XXV) 1969," n.d.

Wilson, Jefferey D. "Mining the Deep Seabed: Domestic Regulation, International Law, and UNCLOS OOO.” Tulsa Law Review 18, no. 2 (2013): 207-60.

Zhang, Guobin, and Pai Zheng. "A New Step Forward: Review of China's 2016 Legislation on International Seabed Area Exploration and Exploitation, Marine Policy." Marine Policy 73 (2016): 244-55.

Zou, Keyuan. "State Practice in Deep Seabed Mining: The Case of the People's Republic of China." Ocean Resource Governance Chapter 9 (2017): 185-203. 